\title{
BIOMETRIC ANALYSIS AND BREAKING OF DORMANCY OF SEEDS OF Piptadenia viridiflora (Kunth) Benth
}

\author{
Anne Caroline Vieira Cangussu ${ }^{1}$, Ana Paula Oliveira Caetano ${ }^{1}$, Jerffson Lucas Santos ${ }^{2}$, Manoel Nelson de \\ Castro Filho ${ }^{1}$, Adriana Dias Cardoso ${ }^{3}$

\footnotetext{
${ }^{1}$ State University of Southwestern Bahia, Graduate Program in Agronomy, Vitória da Conquista, Bahia, Brazil -anne.agro96@gmail.com*; apocaetano@gmail.com; manoel_mrr@hotmail.com.

${ }^{2}$ Federal Institute of Education, Science, and Technology of Santa Catarina, Faculty, Camboriú, Santa Catarina, Brazil je.lucas@hotmail.com.
} \\ ${ }^{4}$ UESB, Researcher CAPES/PNPD/UESB, Vitória da Conquista, Bahia, Brazil - adriuesb@yahoo.com.br
}

Received for publication: 04/09/2017 - Accepted for publication: 26/03/2018

\begin{abstract}
The objective of this study is to evaluate the biometric characteristics and the efficiency of treatments using mechanical scarification and immersion in water at different temperatures to break the dormancy of seeds of surucucu [Piptadenia viridiflora (Kunth) Benth], a tree with several uses and adapted to the semiarid conditions of the northeast of Brazil. The biometric analysis of the seeds was conducted using a digital caliper. The mean length, width, and thickness of 100 seeds were measured. The study adopted a completely randomized experimental design, with six treatments and four repetitions of 25 seeds per plot, totaling 100 seeds per treatment. The experiment consisted of control treatment (seeds without scarification), treatment with mechanical scarification on sandpaper, and heat treatment at $60,70,80$ and $90{ }^{\circ} \mathrm{C}$ for $5 \mathrm{~min}$. The average size of the seeds was $8.050 \mathrm{~mm}$ in length, $6.529 \mathrm{~mm}$ in width, and $0.997 \mathrm{~mm}$ in thickness. For breaking dormancy, scarification on sandpaper and water immersion at $70{ }^{\circ} \mathrm{C}$ produced higher percentages of germination and emerged seedlings.

Keywords: Scarification, germination, emergence, surucucu.
\end{abstract}

\section{Resumo}

Biometria e superação de dormência em sementes de Piptadenia viridiflora (Kunth) Benth. Objetivou-se neste estudo avaliar os caracteres biométricos e a eficiência da utilização de tratamentos com escarificação mecânica (lixa) e imersão em água sob diferentes temperaturas visando à quebra de dormência em sementes de surucucu (Piptadenia viridiflora (Kunth) Benth), árvore adaptada às condições do semiárido do Nordeste e que possui diversos usos. A caracterização biométrica das sementes foi realizada com uso de paquímetro digital. Obtevese a média do comprimento (C), largura (L) e espessura (E) de 100 sementes. O delineamento experimental utilizado para o ensaio de germinação e emergência foi inteiramente casualizado, com seis tratamentos e quatro repetições de 25 sementes por parcela, totalizando 100 sementes por tratamento. O experimento constituiu em um tratamento testemunha (sementes sem escarificação), tratamento com escarificação mecânica em superfície abrasiva (lixa), e tratamento térmico nas temperaturas de $60,70,80$ e $90{ }^{\circ} \mathrm{C}$ por 5 minutos. As médias das dimensões das sementes foram: $8,050 \mathrm{~mm}$ para o comprimento, $6,529 \mathrm{~mm}$ para a largura, e $0,997 \mathrm{~mm}$ para a espessura. Para a quebra da dormência, a escarificação em lixa e a imersão em água a $70{ }^{\circ} \mathrm{C}$ apresentaram maiores porcentagens de germinação e de plântulas emergidas.

Palavras chave: Escarificação, germinação, emergência, surucucu.

\section{INTRODUCTION}

The plant species Piptadenia viridiflora, popularly known as surucucu, is a medium-sized, resilient tree that grows well in dry and low-fertility soils. It is highly adapted to the semi-arid region of the northeast of Brazil. In addition, it is promising for erosion control and recovery of degraded areas and for establishing multiple-use forests, including forests for wood and coal production, because of the high density of the wood (PESSOA et al., 2010). Although it is highly adapted to the biotic and abiotic conditions of the semi-arid region of northeast Brazil and is economically important to this region, the knowledge base necessary for the economic exploration of this species is still limited, especially regarding propagation techniques. However, this knowledge is essential for the systematization of forest management (SANTOS et al., 2014).

Most of the tree legumes have seeds that, even viable, do not germinate (dormant). Dormancy protects the seed against adverse environmental conditions. This mechanism is used by plants to germinate and grow in the season most favorable to development. 
Dormancy may occur by several mechanisms, including impermeability of the tegument to water and gases, formation of immature or rudimentary embryos, special lighting or temperature requirements, and the presence of growth inhibitors, among others (CARVALHO; NAKAGAWA, 2012). Therefore, special treatments are necessary to break dormancy.

The seeds of surucucu and those of other species of the genus Piptadenia, including P. moniliformis and P. gonoacantha, have tegument dormancy (AZEREDO et al., 2010; SANTOS et al., 2015). This characteristic is common in many species of legumes and is one of the fundamental factors for the permanence of the species in the field under conditions of environmental adversity.

The impermeability of the tegument of $P$. viridiflora can be overcome by scarification, which consists in rupturing or weakening the integument because cracked and weakened teguments allow the passage of water, allowing the onset of germination (SANTOS et al., 2014). The scarification by immersion in hot water and mechanical scarification are used to break tegument dormancy in seeds of other forest species, including Caesalpinia ferrea (COELHO et al., 2010), Cassia fistula (GUEDES et al., 2013), and Dioclea violacea (ZUCARELI et al., 2010). The efficiency of these treatments depends on the degree of seed dormancy, which varies among species, and on seed origin and year of collection (ALBUQUERQUE et al., 2007).

The biometric analysis of $P$. viridiflora seeds may provide relevant information on pre-germination treatments, the genetic variability of populations, dispersion characteristics, and establishment of the species. The classification of seeds by size may help improve batch quality considering that Padua et al. (2010) observed that seed size affected seed performance during germination and seedling characteristics.

Therefore, the objective of this study is to determine biometric parameters and the efficiency of methods for breaking the dormancy of sигисиси seeds.

\section{MATERIAL AND METHODS}

The experiment was carried out in the Laboratory of Technology and Production of Seeds of the State University of the Southwest of Bahia (UESB), Vitória da Conquista campus, from August to September 2016. The sигисиси seeds were collected manually in the region of Boquira, state of Bahia, Brazil, and then selected, counted, and stored for later analysis.

The following characteristics were analyzed before installing germination and emergency tests: a) water content, determined in four replicates of 25 seeds each, in an oven at $105 \pm{ }^{\circ} \mathrm{C}$ for 24 hours (BRASIL, 2009); b) electrical conductivity, determined in four replicates of 25 seeds; the seeds were placed in a container with $75 \mathrm{~mL}$ of distilled water and conditioned in BOD at $25^{\circ} \mathrm{C}$ for 24 hours; after that, the conductivity of the solution was read in a conductivity meter (VIEIRA; KRZYANOWSKI, 1999); c) mass of 1,000 seeds in eight repetitions of 100 seeds; the dry weight was measured on an analytical scale with an accuracy of $0.0001 \mathrm{~g}$ (BRASIL, 2009). The following biometric parameters were evaluated using a digital caliper (means of 100 seeds): a) length, b) width (L), and c) thickness.

The treatments used were mechanical scarification on an abrasive surface (sandpaper $\left.\mathrm{n}^{\mathbf{0}} 100\right)$ (T1); immersion in hot water at $60,70,80$, and $90{ }^{\circ} \mathrm{C}$ for $5 \mathrm{~min}$ (T2, T3, T4, T5, respectively); and a control group without treatment (T6). The study adopted a completely randomized experimental design.

One hundred seeds were used per treatment in the germination test, divided into four repetitions of 25 seeds per plot. The seeds were sown on two sheets of Germitest ${ }^{\circledR}$ paper, covered with a third sheet and arranged in rolls. The paper was moistened with distilled water using an equivalent to 2.5 times its dry mass without further adding water. The rolls were packed in transparent plastic bags to avoid water loss by evaporation and kept in a BOD at $25^{\circ} \mathrm{C}$ in the dark. The final evaluations were performed on day 14 after installing the test, and the results were expressed as mean percentages by recording the rate of dormant, dead, and germinated seeds. Dead seeds were considered those that were soft and/or rotten when pressed with the finger, and germinated seeds were those with a primary root protrusion length longer than $2 \mathrm{~mm}$. The first germination count was performed concomitantly with the germination test to determine the percentage of germinated seeds on the seventh day after test installation.

The test of seedling emergence was conducted in a greenhouse using 100 seeds per treatment, divided into four subsamples of 25 seeds. The seeds were sown in plastic trays containing washed sand and were moistened where necessary. The rate of emerged seedlings and the emergence velocity index (EVI) were determined. Daily observations were made from the day of emergence of the first seedling, and the number of seedlings was counted daily until this number remained constant. Seedlings were considered emerged when the cotyledons began to open. At the end of the experiment, the seedlings were harvested and the root length (RL), shoot length (SL), root dry weight (RDW), and shoot dry weight (SDW) were measured. The dry weight was obtained by separating the seedlings in shoot and root, transferring these samples to paper bags, and incubating them in an oven at $65^{\circ} \mathrm{C}$ for 48 hours. After that, the samples were weighed on an analytical scale with an accuracy of $0.0001 \mathrm{~g}$. 
Statistical analysis was conducted using the Sisvar software version 5.6. Analysis of variance was performed, and the means of the treatments were compared using the Tukey test at a level of significance of $5 \%$.

\section{RESULTS}

The mean weight of 1,000 seeds of P. viridiflora was $39.77 \mathrm{~g}$, the mean water content was $9.03 \%$, and the mean electrical conductivity was $24.66 \mu \mathrm{S} \mathrm{cm}^{-1} \mathrm{~g}^{-1}$. The results of biometric analysis of the seeds are presented in Table 1.

Table 1. Mean, mode, standard deviation, and coefficient of variation (CV) of the length, width, and thickness of seeds of Piptadenia viridiflora (Kunth) Benth (Vitória da Conquista, state of Bahia, Brazil, 2016).

Tabela 1. Valores de média, moda, desvio padrão e coeficiente de variação (CV) para o comprimento, largura e espessura de sementes de Piptadenia viridiflora (Kunth) Benth (Vitória da Conquista, Bahia, 2016).

\begin{tabular}{cccc}
\hline & Length $(\mathbf{m m})$ & Width $(\mathbf{m m})$ & Thickness $(\mathbf{m m})$ \\
\hline Mean & 8.050 & 6.529 & 0.997 \\
Mode & 7.800 & 7.280 & 0.960 \\
Standard deviation & 0.737 & 0.689 & 0.104 \\
CV $(\%)$ & 9.154 & 10.547 & 10.403 \\
\hline
\end{tabular}

The data on length, width, and thickness were distributed in three frequency classes (Figure 1). Most seeds presented a length from 8.09 to $9.41 \mathrm{~mm}$ (56\%) (Figure 1A), width from 5.40 to $7.85 \mathrm{~mm}$ (96\%) (Figure 1B), and thickness from 0.86 to $1.04 \mathrm{~mm}(54 \%)$ (Figure 1C).
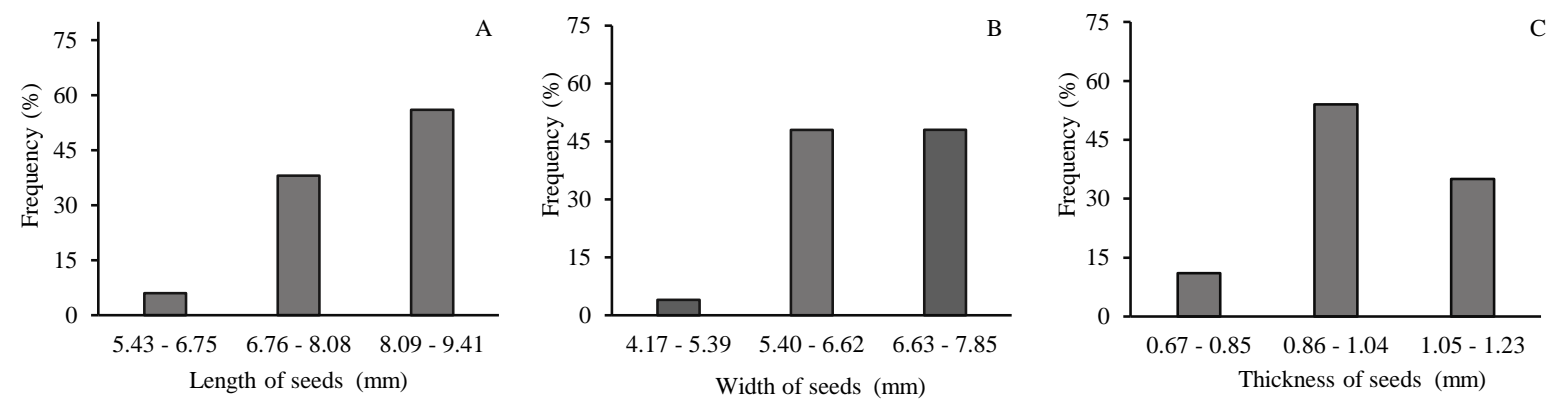

Figure 1. Distribution of the relative frequency of the length (A), width (B), and thickness (C) of seeds of Piptadenia viridiflora (Kunth) Benth.

Figura 1. Distribuição da frequência relativa do comprimento (A), largura (B) e espessura (C) de sementes de Piptadenia viridiflora (Kunth) Benth.

The methods used to break the dormancy of the seeds of surucucu were efficient, and the rate of germination was higher in seeds subjected to mechanical scarification using sandpaper and immersion in water at $70{ }^{\circ} \mathrm{C}$ for $5 \mathrm{~min}$ compared with the other treatments (Table 2). When the water temperature was increased to 80 and $90{ }^{\circ} \mathrm{C}$ for $5 \mathrm{~min}$, it was observed that the seeds were not dormant but dead, considering the higher percentage of dead seeds (Table 2).

Table 2. Initial count (IC) and percentage of germinated seeds (GERM), dormant seeds (DORM), and dead seeds of Piptadenia viridiflora (Kunth) Benth subjected to different methods of breaking the dormancy (UESB, Vitória da Conquista, state of Bahia, Brazil, 2016).

Tabela 2. Primeira contagem (IC) e porcentagem de sementes germinadas (GERM), dormentes (DORM) e mortas de Piptadenia viridiflora (Kunth) Benth, submetidas a diferentes métodos para superação da dormência (UESB - Vitória da Conquista, Bahia, 2016).

\begin{tabular}{ccccc}
\hline Treatments & IC & Germ & Dorm & Dead \\
\cline { 2 - 5 } & & $7.0 \mathrm{~d}$ & $93.0 \mathrm{a}$ & $0.0 \mathrm{~d}$ \\
Control sample & $3.0 \mathrm{~d}$ & $70.0 \mathrm{a}$ & $0.0 \mathrm{~d}$ & $30.0 \mathrm{bc}$ \\
Mechanical scarification & $69.0 \mathrm{a}$ & $43.0 \mathrm{~b}$ & $45.0 \mathrm{~b}$ & $12.0 \mathrm{~cd}$ \\
Heat treatment at $60^{\circ} \mathrm{C}$ & $35.0 \mathrm{bc}$ & $67.5 \mathrm{a}$ & $20.0 \mathrm{c}$ & $15.0 \mathrm{~cd}$ \\
Heat treatment at $70^{\circ} \mathrm{C}$ & $48.0 \mathrm{~b}$ & & & \\
\hline
\end{tabular}

FLORESTA, Curitiba, PR, v. 48, n. 3, p. 355-362, jul/set. 2018.

Cangussu. A.C.V. et.al.

ISSN eletrônico 1982-4688

DOI: $10.5380 /$ rf.v48i3.55068 


\begin{tabular}{ccccc} 
Heat treatment at $80{ }^{\circ} \mathrm{C}$ & $24.0 \mathrm{c}$ & $30.0 \mathrm{bc}$ & $23.0 \mathrm{c}$ & $47.0 \mathrm{ab}$ \\
Hot water at $90^{\circ} \mathrm{C}$ & $15.0 \mathrm{~cd}$ & $19.0 \mathrm{~cd}$ & $15.0 \mathrm{~cd}$ & $66.0 \mathrm{a}$ \\
\hline Mean & 32.33 & 39.42 & 32.67 & 32.86 \\
\hline $\mathrm{CV}(\%)$ & 27.82 & 25.02 & 23.97 & 28.33 \\
\hline TThe
\end{tabular}

The treatments with mechanical scarification and immersion in water at 60 and $70{ }^{\circ} \mathrm{C}$ for 5 min increased EVI and the rate of emergence (RE) compared with the other treatments (Table 3). The mechanical scarification and immersion in water at $60^{\circ} \mathrm{C}$ for 5 min yielded higher SL than water immersion treatments at 80 and $90{ }^{\circ} \mathrm{C}$ for $5 \mathrm{~min}$ (Table 3). The RDW was higher in seeds immersed in water at 60,70 , and $80^{\circ} \mathrm{C}$ for $5 \mathrm{~min}$. However, none of the treatments significantly affected the RL and SDW (Table 3).

Table 3. Emergence velocity index (EVI), rate of emergence (RE), shoot length (SL), root length (RL), shoot dry weight (SDW), and root dry weight (RDW) of Piptadenia viridiflora seedlings subjected to different methods of breaking dormancy (UESB, Vitória da Conquista, state of Bahia, Brazil, 2016).

Tabela 3. Índice de velocidade de emergência (EVI), porcentagem de emergência (RE), comprimento da parte aérea e raiz (SL e RL) e massa seca da parte aérea e raiz (SDW e RDW) de plântulas de Piptadenia viridiflora, submetidas a diferentes tratamentos de superação de dormência (UESB - Vitória da Conquista, Bahia, 2016).

\begin{tabular}{ccccccc}
\hline Treatments & EVI & RE & SL & RL & SDW & RDW \\
\cline { 2 - 7 } & \multicolumn{2}{c}{$\%$} & \multicolumn{2}{c}{$\mathbf{c m}$} & & \multicolumn{2}{c}{ mgpl $^{-1}$} \\
\hline Control sample & $0.22 \mathrm{c}$ & $6.0 \mathrm{c}$ & $4.24 \mathrm{abc}$ & $4.63 \mathrm{a}$ & $7.75 \mathrm{a}$ & $3.50 \mathrm{c}$ \\
Mechanical scarification & $1.59 \mathrm{a}$ & $54.0 \mathrm{a}$ & $4.50 \mathrm{a}$ & $5.47 \mathrm{a}$ & $8.71 \mathrm{a}$ & $4.55 \mathrm{ab}$ \\
Hot water at $60^{\circ} \mathrm{C}$ & $1.41 \mathrm{a}$ & $47.0 \mathrm{a}$ & $4.59 \mathrm{a}$ & $5.71 \mathrm{a}$ & $8.80 \mathrm{a}$ & $4.97 \mathrm{a}$ \\
Hot water at $70^{\circ} \mathrm{C}$ & $1.63 \mathrm{a}$ & $58.0 \mathrm{a}$ & $4.47 \mathrm{ab}$ & $5.92 \mathrm{a}$ & $7.58 \mathrm{a}$ & $4.87 \mathrm{a}$ \\
Hot water at $80^{\circ} \mathrm{C}$ & $0.83 \mathrm{~b}$ & $28.0 \mathrm{~b}$ & $3.96 \mathrm{c}$ & $5.73 \mathrm{a}$ & $7.47 \mathrm{a}$ & $4.90 \mathrm{a}$ \\
Hot water at $90^{\circ} \mathrm{C}$ & $0.30 \mathrm{bc}$ & $11.0 \mathrm{cB}$ & $4.01 \mathrm{cB}$ & $4.89 \mathrm{a}$ & $6.89 \mathrm{a}$ & $3.89 \mathrm{bc}$ \\
\hline Mean & 0.10 & 34.00 & 4.29 & 5.39 & 7.86 & 4.45 \\
\hline $\mathrm{CV}(\%)$ & 24.46 & 24.25 & 4.97 & 17.17 & 11.02 & 8.15 \\
\hline
\end{tabular}

*The means followed by the same letter in the column do not differ from each other using the Tukey test at a level of significance of $5 \%$.

\section{DISCUSSION}

Limiting the plant's energy resource in the seed development period by environmental factors, including temperature, water, and the chemical structure of the soil, increases the variability in seed size. Baskin and Baskin (2014) reported that different seed sizes in the same species might be correlated with variations in the environment where the plant was located. A low coefficient of variation indicates that sampling and biometric analysis presented a low dispersion around the mean, which determines data homogeneity and reliability.

Fontenele et al. (2007) noted that biometric analysis might provide subsidies for studying species differentiation, classification of ecological groups, and genetic divergences in the same species. Despite the homogeneous distribution of the data, there was a small fluctuation in length, width, and thickness, corresponding to $5.43-9.41 \mathrm{~mm}, 4.17-7.85 \mathrm{~mm}$, and $0.67-1.23 \mathrm{~mm}$, respectively. However, these variations and differences in data homogeneity are common in tree species with different parent plants. In this respect, Pereira et al. (2011) performed a biometric analysis of Hymenaea stigonocarpa and found that the variability in fruit size was correlated with the genetic variability of populations of the same species, and Oliveira et al. (2012) reported that the seeds of Anadenanthera macrocarpa (Benth.) also presented variability.

Matsumoto et al. (2010) studied P. viridiflora and observed that the rate of germination was low (maximum of $17.98 \%$ and minimum of $13.00 \%$ ) in germination tests conducted without breaking dormancy. The authors indicated that these results were due to the high percentage of seeds with tegument impermeability.

Pessoa et al. (2010) studied maturation stages and their interaction with the conservation of surucucu seeds and noted that the percentage of hard seeds was high (33-63\%) in the lots, and the rate of germination was low because of the high percentage of seeds with tegument impermeability. Therefore, mechanical scarification was more efficient than water immersion considering that the initial count of seedlings was higher than that for the other treatments and the first lot of seedlings was more homogeneous (Table 2).

Araújo Neto et al. (2014) observed tegument dormancy in seeds of Caesalpinia pulcherrima (L.) SW. and, for this species, scarification was the best method to obtain higher rate of germination. Guedes et al. (2013) examined seeds of Cassia fistula L. and found that the percentage of dead seeds was higher when water treatment 
at high temperatures was used for breaking dormancy. The authors indicated that this result was due to the loss of seed viability, and embryo death was evidenced by the flaccidity of the seed tissues.

Santos et al. (2014) evaluated methods of breaking dormancy by chemical scarification with sulfuric acid and observed that the rate of emergence in a greenhouse was low in seeds not subjected to scarification. Zucareli et al. (2010) compared mechanical and chemical scarification in sulfuric acid for breaking dormancy and obtained similar results for the emergence of seedlings of Dioclea violacea. However, they emphasized that the former method was the safest and most economically feasible. Pereira et al. (2016) highlighted that it might be difficult to perform this treatment in mechanical scarification for a large number of seeds.

The increase in water temperature caused a decrease in EVI and RE, demonstrating that the development of the surисиси seedlings was compromised at higher temperatures. This result is due to the increase in the number of dead seeds because very high temperatures damage the seed embryo. In this respect, Oliveira (2008) studied the germination of leucena seeds and noted that high temperatures negatively affected the seed physiology and embryo viability, delaying germination and/or causing death. Coelho et al. (2010) observed that immersion in water at high temperatures caused severe damage to embryonic tissues, impairing germination.

The SL of seedlings was higher in seeds subjected to immersion in water at 60 and $70{ }^{\circ} \mathrm{C}$ for 5 min and to scarification. However, these treatments did not differ significantly from the control. Seeds that emerged faster presented higher SL values, and these values agreed with EVI values. The opposite occurred at higher temperatures $\left(80\right.$ and $90{ }^{\circ} \mathrm{C}$ ), at which plant growth was adversely affected. In contrast, Machado et al. (2013) evaluated the effect of pre-germinative treatments in breaking the dormancy of Piptadenia moniliformis Benth seeds and found no significant differences between treatments, except for the treatment of immersion in water at $100{ }^{\circ} \mathrm{C}$. Furthermore, most of the germinated seeds had deficiencies and did not grow, and this result was similar to that of the treatments by immersion of $P$. viridiflora in water at 80 and $90{ }^{\circ} \mathrm{C}$.

The SDW was similar between treatments, indicating that even at different lengths, this species was not affected by the accumulation of mass generated by the treatments used to break dormancy. Ferreira et al. (2009) found no significant differences in RL, SL, and RDW in Rollinia mucosa (Jacq.) Baill seedlings between the treatments used to break dormancy.

However, there was a significant difference in RDW between treatments. The RDW was lowest in the control treatment and treatment with water at $90{ }^{\circ} \mathrm{C}$ for $5 \mathrm{~min}$. These results might be because no process of breaking of dormancy was used in the control group, and therefore the seeds took longer to germinate. This result was confirmed in the analysis of EVI. Therefore, root growth in the control treatment was lower because of the shorter period of growth compared to that in seeds whose dormancy was overcome.

With regard to treatment by immersion in water at $90{ }^{\circ} \mathrm{C}$ for $5 \mathrm{~min}$, the seeds were affected because of their exposure to high temperatures, retarding their development. Coelho et al. (2010) studied Caesalpinia ferrea and found significant differences in RDW in the control group and the group treated by immersion in water at 100 ${ }^{\circ} \mathrm{C}$, and the RDW was smaller than that in seeds subjected to scarification. Santos et al. (2013) reported that SL, RL, and SDW, and RDW were highest in Erythrina velutina seeds subjected to mechanical scarification, and immersion in hot water did not break dormancy. Gama et al. (2011) and the present study reported similar values for these parameters in treatment by immersion in hot water and scarification on sandpaper for seeds of Centrosema plumieri Benth.

These discrepancies indicate that, even when the species have the same type of dormancy, tests for overcoming dormancy should be performed to determine which species can reach maximum values of germination and vigor of dormant seeds.

\section{CONCLUSION}

- The biometric characteristics of $P$. viridiflora seeds present variability.

- The mechanical scarification on sandpaper and immersion in water at $70^{\circ} \mathrm{C}$ for $5 \mathrm{~min}$ are efficient to overcome tegument dormancy in the seeds of suruсиси.

\section{ACKNOWLEDGMENTS}

The authors are grateful to Professor Otoniel Magalhães Morais (in memoriam) for the valuable contribution in this research.

FLORESTA, Curitiba, PR, v. 48, n. 3, p. 355-362, jul/set. 2018.

Cangussu. A.C.V. et.al.

ISSN eletrônico 1982-4688

DOI: $10.5380 /$ rf.v48i3.55068 


\section{REFERENCES}

ALBUQUERQUE, K. S.; GUIMARÃES, R. M.; ALMEIDA, I F. DE; CLEMENTE, A. DA C. S. Métodos para a superação da dormência em sementes de sucupira-preta (Bowdichia virgilioides Kunth.). Ciência e Agrotecnologia, Lavras, v. 31, n. 6, p. 1716-1721, 2007.

ARAÚJO NETO, J.C. de; CAMARA, C. de A.; FERREIRA, V.M.; LESSA, B. F. da T.; OLIVEIRA, Y. de M. O. Caracterização morfológica, germinação e conservação de sementes de Caesalpinia pulcherrima (L.) SW. (Fabaceae: Caesalpinioidea). Semina: CiênciasAgrárias, Londrina, v.35, n.4, p.2287-2300, 2014.

AZEREDO, G. A.; PAULA, R. C.; VALERI, S. V.; MORO, F. V. Superação de dormência de sementes de Piptadenia moniliformis Benth. Revista Brasileira de Sementes, Londrina, v. 32, n. 2, p. 49-58, 2010.

BASKIN, C.C.; BASKIN, J.M. Seeds: ecology, biogeography, and evolution of dormancy and germination, 2 ed. San Diego, CA, USA: Academic/Elsevier, 2014. 1600p.

BRASIL. Ministério da Agricultura, Pecuária e Abastecimento. Regras para análise de sementes. Ministério da Agricultura, Pecuária e Abastecimento. Secretaria de Defesa Agropecuária. Brasília, DF: Mapa/ACS, 2009. 395p.

CARVALHO, N. M.; NAKAGAWA, J. Sementes: ciência, tecnologia e produção. Jaboticabal: FUNEP, 5 ed. 2012. 590p.

COELHO, M. F. B.; MAIA, S. S. S.; OLIVEIRA, A. K.; DIÓRGENES, F. E. P. Superação da dormência tegumentar em sementes de Caesalpinia férrea Mart ex Tul. Revista Brasileira de Ciências Agrárias, Recife, v.5, n.1, p.74-79, 2010.

FERREIRA, M. G. R.; SANTOS, M. R. A.; SILVA, E. O.; GONÇALVES, E. P.; ALVES, E. U.; BRUNO, R. L. A. Superação de dormência em sementes de biribá (Rollinia mucosa (Jacq.) Baill). Revista Brasileira de Sementes, Londrina, v. 31, n. 4, p.095-099, 2009.

FONTENELE, A. C. F.; ARAGÃO, W. M.; RANGEL, J. H. A. Biometria de frutos e sementes de Desmanthus virgatus (L) Willd do Sergipe. Revista Brasileira de Biociências, Porto Alegre, v. 5, supl. 1, p. 252-254, 2007.

GAMA, J. S. N.; ALVES, E. U.; BRUNO, R. L. A.; PEREIRA JUNIOR, L. R.; MARTINS JUNIOR, J. B.; MONTE, D. M. O. Superação de dormência em sementes de centrosema plumieri Benth. Revista Brasileira de Sementes, Londrina, v. 33, n. 4 p. 000 - 000, 2011.

GUEDES, R.S.; ALVES, E. U.; SANTOS-MOURA, S. S.; COSTA, E. G.; DE MELO, P. A. F. R.; Tratamentos para superar dormência de sementes de Cassia fistula L. Revista Biotemas, Florianópolis, v.26, n.4, p.11-22, 2013.

MACHADO, J. S.; SOUZA, W. M. F.; LUSTOSA JÚNIOR, I. M.; SANTOS, L. M.; FARÍAS, F. G. G. Tratamentos pré-germinativos para superação de dormência em sementes de Angico. Cerrado Agrociências, Patos de Minas, n. 4, p. 27-34, 2013.

MATSUMOTO, S. N. M.; PESSOA, R. C.; LIMA, J. M.; VIANA, A. E. S.; CASTELlANI, M. A.Aspectos de maturação de vagens e sementes de Piptadenia viridiflora relacionados a germinação e dormência. Revista Pesquisa Aplicada \& Agrotecnologia, v. 3 n. 1, p. 617- 625, 2010.

OLIVEIRA, A. B. Germinação de sementes de leucena (Leucaena leucocephala (Lam.) De Wit.), var. K-72. Revista de Biologia e Ciências da Terra, v. 08, n. 02, p. 166-172, 2008.

OLIVEIRA, S. S. C. de; ARAÚJO NETO, J. C. de; CRUZ, S. J. S.; FERREIRA, V. M. Caracterização morfométrica de sementes e plântulas e germinação de Anadenanthera macrocarpa (Benth.) Brenan. Ciência Florestal, Santa Maria, v. 22, n. 3, p. 643-653, 2012.

PÁDUA, G. P. de; ZITO, R. K.; ARANTES, N. E.; NETO, J. de B. F. Influência do tamanho da semente na qualidade fisiológica e na produtividade da cultura da soja. Revista Brasileira de Sementes, vol. 32, no 3 p. 009016, 2010.

PEREIRA, A. G.; CRUZ, E. D.; BARROS, H. S. D. Methods for overcoming dormancy in Stryphnodendron pulcherrimum seeds. Pesquisa Florestal Brasileira, Colombo, v. 36, n. 87, p. 195-199, 2016.

PEREIRA, S.R.; GIRALDELLI, G.R.; LAURA, V.A.; SOUZA, A.L.T. Tamanho de frutos e de sementes e sua influência na germinação de jatobá-do-cerrado (Hymenaea stigonocarpa var. stigonocarpamart. ex. Hayne, leguminosae - caesalpinoideae). Revista Brasileira de Sementes, Londrina, v.33, n.1 p.141-148, 2011. 
PESSOA, R. C.; MATSUMOTO, S. N.; MORAIS, O. P.; DO VALE, R. S.; LIMA, J. M. Germinação e maturidade fisiológica de sementes de Piptadenia viridiflora (kunth.) benth relacionadas a estádios de frutificação e conservação pós-colheita. Revista Árvore, Viçosa, v.34, n.4, p.617-625, 2010.

SANTOS, J. L.; LUZ, I. S.; MATSUMOTO, S. N.; D’ARÊDE, L. O.; VIANA, A. E. S. Superação da dormência tegumentar de sementes de Piptadenia viridiflora (Kunth) Benth pela escarificação química. Bioscience Journal, Uberlândia, v. 30, n. 6, p. 1642-1651, 2014.

SANTOS, L. W. DOS; COElHO, M. F. B.; MAIA, S. S. S.; SILVA, R. C. P.; CÂNDIDO, W. S.; SILVA, A. C. Armazenamento e métodos para a superação da dormência de sementes de mulungu. Semina: Ciências Agrárias, Londrina, v. 34, n. 1, p. 171-178, 2013.

SANTOS, M. M.; LARA, R. O.; de JESUS, L. L. Germinação e superação de dormência de sementes de espécies florestais. Enciclopédia biosfera, Centro Científico Conhecer - Goiânia, v.11 n.22, p. 1409-1417, 2015.

VIEIRA, R. D.; KRZYZANOWSKI, F. C. Teste de condutividade elétrica. In: KRZYZANOWSKI, F. C.; VIEIRA, R. D.; FRANÇA NETO, J.B. (eds). Vigor de sementes: conceitos e testes. Londrina: ABRATES. cap.4, 1999, p.1-26.

ZUCARELI, V.; AMARO, A. C. E.; SILVÉRIO, E. V.; FERREIRA, G. Métodos de superação da dormência e temperatura na germinação de sementes de Dioclea violácea. Semina: Ciências Agrárias, Londrina, v. 31, n.1, p. 1305-1312, 2010. 
FLORESTA, Curitiba, PR, v. 48, n. 3, p. 355-362, jul/set .2018.

Cangussu. A.C.V. et.al. 